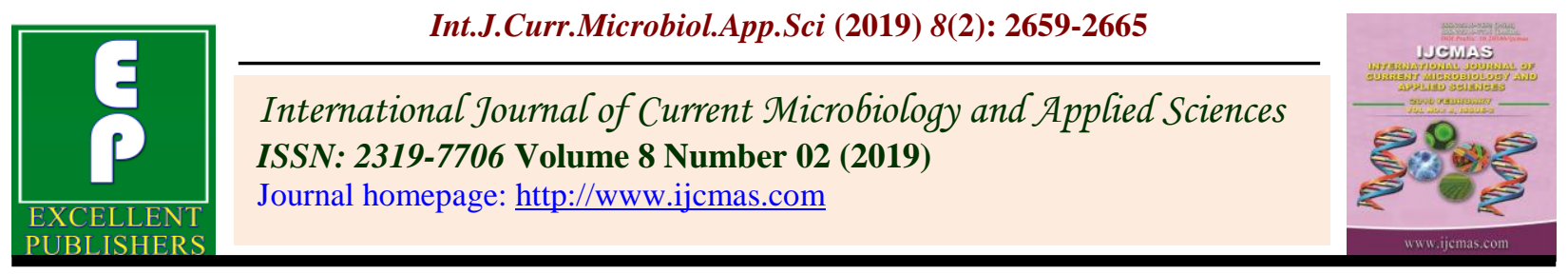

Review Article

https://doi.org/10.20546/ijcmas.2019.802.311

\title{
Punja Durrie: A Diminishing Textile Craft of Haryana
}

\author{
Saroj Yadav* and Neelam M. Rose \\ Department of Textile and Apparel Designing, I.C. College of Home Science, CCS Haryana \\ Agricultural University, Hisar, India \\ *Corresponding author
}

\begin{abstract}
A B S T R A C T
\end{abstract}
The village and cottage craft play a pivotal role in the social and economic life of our country. These not only fulfill needs of our daily life but also act as mode of self expression and a source of income generation. Pottery, embroidery and handloom weaving

Keywords

Punja Durrie,

Textile Craft of Haryana

Article Info

Accepted:

20 January 2019

Available Online:

10 February 2019 are some of the famous crafts of Haryana. Punja durries are familiar objects in almost every household in the villages of Haryana and is mainly practiced as a leisure time activity by women. Durries are traditionally made for two purposes, one for bed in place of mattress or below a thin mattress and other for floor covering. Once, durrie making was highly preferred activity for income generation among rural women. But due to tough competition from powerloom industry and change consumer preferences this age old craft is at the verge of diminishing. A study was conducted in Hisar, Fatehabad and Sirsa districts of Haryna state to study the status of punja durrie craft. It was found that the craft was being practiced by women and majority $80 \%$ ) of them adopted durrie weaving as subsidiary occupation to support their family income. Besides durrie they also prepared foot mat, prayer mat, stool mat and bags. Mainly floral/foliage, geometrical, animals and birds motifs were used. Most of the products were sold in the village itself with a profit of 10-20 percent. The respondents discontinued the craft mainly due lack of demand (100\%), the younger generation is not interested in adopting this craft (100\%), less profit and time consuming craft $(92.22 \%$ each).

\section{Introduction}

From the time immemorial, the traditional cottage crafts seemed to have played a pivot role in social and economic life of mankind. These not only manifested service to the positive needs in daily life but acted as a mode of self expression which revealed as a conscious aesthetic approval. Haryana is known for its exquisite handloom traditions. The creativity of Haryana is visible in the rich art work and unique handloom and hand embroidery. Punja durries are familiar objects in almost every household in the villages of Haryana and is mainly practiced as a leisure time activity by women. The craft gets its name from a metallic claw-like tool called punja in the local dialect, used to beat and set the filling threads. The punja durries are mostly woven in bright colours using myriad motifs. The designs are varied and are skillfully made to enhance the aesthetic appeal of these durries. These are woven into stripes, check boards, squares, and pictures of 
birds, animals, human figures and plants etc. and are used on floors, beds and diwan (www.swadesi.com).

In Haryana, durrie making is undertaken in almost all the districts. The tradition of weaving durries is the exclusive preserve of women. A girl is taught to weave by older women of the household- her mother, grander mother, paternal aunt or sister at a very young age. They continue practicing durrie weaving during their leisure time (Yadav et al., 2008). Durrie weaving in rural Haryana though has a seal of social approval but this textile heritage is facing tough competition from the modern mechanized and commercialized methods of producing durries. Further, durrie weaving craft is diminishing day by day due to lack of demand, poor marketing channels, lack of incentive for attainment of creative element and professional efficiency (Kaur, 2009).

Therefore, this age-old textile craft of Haryana which has been an integral part of their lifestyle through generations calls for a special attention so that it can be preserved for the posterity. The traditional art form can be preserved and diversified by adapting the traditional motifs into contemporary forms and incorporating them into the textile by the use of various techniques of designing as use of traditional motifs in textile keep our motifs and designs alive.

\section{Materials and Methods}

A preliminary survey was carried out to get the desired information from primary sources i.e. durrie weavers along with exploration of secondary sources such as prepared durrie, books, internet etc.

\section{Preparation of interview schedule}

Keeping in mind the objectives of the study, interview cum observation technique was used to collect information about punja durrie craft from the respondents. A self structured interview schedule was prepared in consultation with subject matter specialists and after extensive review of literature to gather the requisite information pertaining to punja durrie weaving craft of Haryana. Structured questionnaire comprising of open ended questions was designed and used. The questions were made short and clear in order to ensure that it should be understood by the respondents.

\section{Selection of respondents}

To collect desired information about socio economic background of the respondents and punja durrie craft, ninety respondents were selected from three districts of Haryana state i.e. Hisar, Fatehabad and Sirsa. Three villages from each district were selected on the basis of availability of respondents who were engaged in punja durrie weaving, ten respondents from each village were selected through purposive sampling technique. Hence, total ninety respondents were selected to gather the information.

\section{Data collection}

Structured interview schedule was used for collection of required information. This technique was considered as most appropriate technique to collect depth information from respondents as there is face to face interaction between respondents and researcher, which facilitates clarification of doubts, if any.

The data was collected personally from the respondents in an informal manner after establishing good rapport. Firstly, purpose of the study was explained and required information about punja durrie was collected and tabulated as structured interview schedule. 


\section{Tabulation of data}

The data was compiled and tabulated using frequency and percentages.

\section{Results and Discussion}

The respondents under study used to practice the craft of durrie weaving during earlier times and now they have discontinued this work.

The data regarding personal profile of the respondents revealed that maximum number (44.84\%) of respondents belonged to the age group of above 60 years followed by 24.44 percent respondents in the age group of 50-60 years.

All the respondents were female and majority $(62.22 \%)$ of them were illiterate, belonged to nuclear $(75.55 \%)$ medium sized family $(71.11 \%)$ having farming as their main family occupation $(75.55 \%)$.

The majority of the respondents had annual family income from Rs. 1 to 1.25 lacs and majority of them were engaged by themselves only for weaving of durrie as none of the other family members were involved in this business.

The respondents learnt this art of punja durrie weaving at an early age from their relatives or family members and did not have any formal training of this craft. They started this work out of their own interest.

The data in Table 1 indicate that majority of the respondents i.e. 80.00 percent adopted durrie weaving as subsidiary occupation to support their family income while 72.00 percent respondents also adopted durrie weaving as an occupation to meet out their family expenditure with the expansion of family. 35.55 percent respondents started durrie weaving because of their interest in this craft, 31.11 percent respondents reported that they prepared the gift items for their daughters or other relatives for presenting to them at the time of marriage and ritual ceremonies and 27.77 percent respondents adopted this craft to utilize their leisure time in lean periods of farming seasons. Singh and Malhi, 1989 also found that majority of the respondents made durries for their own use and not for sale.

It is clear from the Table 2 that besides durrie weaving the respondents also prepared stool mat $(91.11 \%)$, foot mat $(80 \%)$, prayer mat $(72.22 \%)$ and bags from the left over material for household uses as well as for sale. Jaiswal, 2000 and Rao, 2003 found that besides durrie, weavers also prepare Galicha, Assan and prayer mats. Jangir, 2005 in a study found that the modern products from the durrie weaving industry were wall hanging, cushions, Aasan and door mats.

The motifs/designs are often repetitive and symbolic to nature. The perusal of Table 3 indicates that the respondents used different type of motifs/designs for durrie i.e. floral/foliage, geometrical, animals and birds motifs. Few respondents also used miscellaneous motifs for durrie weaving. Singh and Malhi, 1989 and Rao, 2003 also reported that the main designs for durrie were geometrical, stylized floral and figurative.

The various methods were being used by the respondents to preserve the motifs/ designs. 75.55 percent respondents prepare a prototype sample of the design, 57.77 percent respondents replicate the design on matte fabric, few respondents $(35.55 \%)$ take the photographs of the designs for future reference while 25.55 percent respondents reported that they draw the design on paper for their record (Table 4). 
All the respondents (100\%) reported that they used to sale their products in the village itself whereas 24.44 percent respondents also used to sale their products in different villages through the relatives, 20.00 percent respondents also used to sale their products through DRDA when a durrie weaving centre was run by DRDA in their village and only 6.66 percent respondents reported that they visited different fairs and exhibitions for selling their products (Table 5).

As reported by 80.00 percent respondents the profit was very less i.e. 10 to 20 percent only while 38.88 percent respondents reported that sometimes they got profit of 20 to 30 percent and few respondents $(24.44 \%)$ also got 30 to 40 percent profit at certain occasions only (Table 6).

Data pertaining to various problems faced by the respondents engaged in durrie weaving are presented in Table 7. It is clear from table that the main problem faced by all the respondents (100\%) was lack of demand of punja durrie, 95.55 percent respondents opined that there was less profit in this business, the respondents also faced the problem in marketing their products due to lack of marketing channels (91.11\%), 75.55 percent respondents reported that most of the sale is on credit basis and the payments were delayed.

Lata (1989) reported that durrie weavers faced problems of low sale price and poor marketability, inadequate skill, tiring job, inadequate finances and non availability of raw materials. Vardrajan (1999) analyzed that lack of adequate market outlets dampens the enthusiasm of artisans. Rao (2003) reported that majority of respondents pointed out different problems like finance, lack of Govt. support and lack of availability of new designs.
As the durrie weaving requires longer working hours and respondents faced different health problems due to their work posture as well as well concentration required in the work. The data pertaining to various health problems faced by the respondents engaged in durrie weaving revealed that the different problems faced by the respondents were general fatigue $(100 \%)$ due longer working hours, headache $(80.00 \%)$, pain in knees/ legs (75.55\%), eye strain (62.22\%), wrist pain $(50.00 \%)$ and few respondents also reported the problems of pain in neck and shoulders $(42.22 \%)$ and cuts in fingers $(13.33 \%)$ due to hardness of warp yarn (Table 8).

The Table 9 indicate that various reasons for discontinuation of durrie craft were lack of demand $(100 \%)$, as the interior settings of households have changed, the charpai are replaced by double beds, hence the demand for durrie have declined. The other reasons stated were less profit and time consuming craft $(92.22 \%$ each), the respondents reported that minimum 15 to 20 days are required to prepare a durrie, and hence the profit gain is very less. As most of the sale was in their own village on credit basis, the respondents got their payments very late after repeated requests for payments and even sometimes the payment is not made in cash. The punja durrie face competition with the durrie woven on looms as the prices are low as compared to hand woven punja durrie. The elderly respondents also discontinued the craft due to their growing age $(75.55 \%)$ and general health problems (62.22\%). The younger generation of the families are not interested in adopting this craft $(100 \%)$ as they want to do jobs or other works, hence they are not taking the legacy forward or to adopt it as an occupation. As most of durrie were made on order and demand of the consumers, the domestic requirements of this craft is limited to a particular strata of society. 
Table.1 Reason for adopting durrie weaving as occupation N=90

\begin{tabular}{|c|c|c|}
\hline Variables & Frequency & Percentage \\
\hline Main family occupation & 65 & 72.22 \\
\hline Subsidiary occupation & 72 & $\mathbf{8 0 . 0 0}$ \\
\hline Interest in the craft & 32 & 35.55 \\
\hline To utilize the leisure time & 25 & 27.77 \\
\hline To prepare gift articles & 28 & 31.11 \\
\hline
\end{tabular}

*Multiple responses

Table.2 Other woven products prepared by the respondents N=90

\begin{tabular}{|l|c|c|}
\hline Products & Frequency & Percentage \\
\hline Foot mat & 72 & 80.00 \\
\hline Prayer mat & 65 & 72.22 \\
\hline Stool mat & 82 & 91.11 \\
\hline Bag & 09 & 10.00 \\
\hline
\end{tabular}

*Multiple responses

Table.3 Motifs/ designs used for durrie weaving N=90

\begin{tabular}{|l|c|c|}
\hline Motifs/ Designs & Frequency & Percentage \\
\hline Floral/ foliage & 90 & 100 \\
\hline Geometrical & 90 & 100 \\
\hline Animals & 90 & 100 \\
\hline Birds & 90 & 100 \\
\hline Miscellaneous & 20 & 22.22 \\
\hline
\end{tabular}

*Multiple responses

Table.4 Methods of preservation of developed designs/motifs N=90

\begin{tabular}{|l|c|c|}
\hline Methods of preservation & Frequency & Percentage \\
\hline Prepare a prototype sample & 68 & 75.55 \\
\hline $\begin{array}{l}\text { Replicate the design on matte } \\
\text { fabric }\end{array}$ & 52 & 57.77 \\
\hline Take photographs & 32 & 35.55 \\
\hline Draw on paper & 23 & 25.55 \\
\hline
\end{tabular}

*Multiple responses 
Table.5 Place of marketing for prepared durrie $\mathrm{N}=90$

\begin{tabular}{|l|c|c|}
\hline Place of sale & Frequency & Percentage \\
\hline Own village & 90 & 100.00 \\
\hline Other villages & 22 & 24.44 \\
\hline Exhibition/ Fairs & 06 & 06.66 \\
\hline Govt. agencies (DRDA) & 18 & 20.00 \\
\hline
\end{tabular}

*Multiple responses

Table.6 Profit earned by the respondents from sale of durrie $\mathrm{N}=90$

\begin{tabular}{|l|c|c|}
\hline Profit (\%) & Frequency & Percentage \\
\hline $\mathbf{1 0 - 2 0}$ & 72 & 80.00 \\
\hline $\mathbf{2 0 - 3 0}$ & 35 & 38.88 \\
\hline $\mathbf{3 0 - 4 0}$ & 22 & 24.44 \\
\hline *Multiple responses & & \\
\hline
\end{tabular}

*Multiple responses

Table.7 Problems faced by the respondents in marketing of prepared durrie $\mathrm{N}=90$

\begin{tabular}{|l|c|c|}
\hline Problems faced & Frequency & Percentage \\
\hline Lack of demand & 90 & 100.00 \\
\hline Less profit gain & 86 & 95.55 \\
\hline Delay in payments & 68 & 75.55 \\
\hline $\begin{array}{l}\text { Lack of marketing } \\
\text { channels }\end{array}$ & 82 & 91.11 \\
\hline Sale is on credit basis & 68 & 75.55 \\
\hline
\end{tabular}

*Multiple responses

Table.8 Health problems faced by the respondents in durrie weaving N=90

\begin{tabular}{|l|c|c|}
\hline Problems faced & Frequency & Percentage \\
\hline Headache & 72 & 80.00 \\
\hline Eye strain & 56 & 62.22 \\
\hline $\begin{array}{l}\text { Pain in neck and } \\
\text { shoulders }\end{array}$ & 38 & 42.22 \\
\hline Pain in wrist & 45 & 50.00 \\
\hline Cuts in finger & 12 & 13.33 \\
\hline Pain in knees/legs & 68 & 75.55 \\
\hline General Fatigue & 90 & 100.00 \\
\hline
\end{tabular}

*Multiple responses 
Table.9 Reasons for discontinuing the craft $\mathrm{N}=90$

\begin{tabular}{|l|c|c|}
\hline Reasons & Frequency & Percentage \\
\hline Growing age & 68 & 75.55 \\
\hline Health problems & 56 & 62.22 \\
\hline Lack of demand & 90 & 100.00 \\
\hline Market competition with durries woven on looms & 78 & 86.66 \\
\hline $\begin{array}{l}\text { Younger generation not interested to adopt the } \\
\text { craft }\end{array}$ & 90 & 100.00 \\
\hline Time consuming task & 83 & 92.22 \\
\hline Less profit & 83 & 92.22 \\
\hline Delay in payments & 78 & 86.66 \\
\hline
\end{tabular}

*Multiple responses

In conclusion, the study conducted to find out the present status of traditional punja durrie craft of Haryana revealed that mainly women were engaged in this craft. The main motifs used were geometrical, floral/ foliage and animal/ bird motifs. The women weavers practiced this craft to utilize their leisure time and support the family income. Respondents discontinued the durrie weaving due to less profit, lack of demand and various health problems faced by them, hence this age old tradition is vanishing. It may be concluded that lack of adequate market outlets dampens the enthusiasm of artisans who need to be helped in terms of product design, consumer preference, latest product styles and designs. Handicraft articles are appreciated in the overseas market, therefore, efforts should be made to identify and explore the export market for durries.

\section{References}

Jaiswal, P. 2000. Study of existing and innovative durrie designs. M.Sc. Thesis, CCS Haryana Agricultural University, Hisar.

Jangir, R. 2005. Development of new designs for durrie and niwar products. M.Sc. Thesis,
Banasthali Vidyapith, Banasthali.

Kaur, N. 2002. Production and Marketing of durries in different socio-cultural zones of Punjab. Ph.D Thesis, Punjab Agricultural University, Ludhiana.

Lata, V. 1989. Impact of Training of Rural Youth for Self-Employment (TRYSEM) programme on status of women. Ph.D. Thesis, CCS Haryana Agricultural University, Hisar.

Singh, O.P. and Malhi, K. 1989. Durrie weaving in rural Ludhiana. Indian Textile Journal. 99(5): 142-145.

Rao, D. 2003. A study on durrie weaving practice in Haryana. M.Sc. Thesis, CCS Haryana Agricultural University, Hisar.

Vradarajan, P.K. 1990. Rural industrializationProgess and prospects. Kurukshetra, 38(7): 43 .

Yadav, N., Sangwan, N. and Khambra, K. 2008. Durrie Weaving as income generation-An exploratory Study. Journal of Human Ecology, 24(1): 41-45.

Swadesi5. 2016. www.swadesi.com/ news/panjaweaving/

\section{How to cite this article:}

Saroj Yadav and Neelam M. Rose. 2019. Punja Durrie: A Diminishing Textile Craft of Haryana. Int.J.Curr.Microbiol.App.Sci. 8(02): 2659-2665.

doi: https://doi.org/10.20546/ijcmas.2019.802.311 